\title{
The radical rationalization of management thought: its causes and consequences
}

\author{
P. Human \\ School of Business Leadership, University of South Africa
}

Radical rationalization refers to the phenomenon where means are seen as ends-in-themselves. Translated to the practice of management this would mean that the exercise of techniques is absolutized to the extent that ends (goals) are lost from sight. In this article we enquire into the causes as well as the consequences of this phenomenon. It is argued that the nature of science as well as the nature of the bureaucratic organization can be seen as causal factors to the 'iron cage' of radical rationalization. Some of those familiar 'iron cages' such as strategic planning, industrial relations, behaviour modelling and the personal computer are discussed.

S. Afr. J. Bus. Mgmt. 1986, 17: 7-12

Die konsep radikale rasionalisasie verwys na die verskynsel waar middele gesien word as doele-in-sig-self. Dit beteken dat tegnieke verabsoluteer word ten koste van doele in die bestuurspraktyk. In hierdie artikel word die oorsake en gevolge van hierdie verskynsel ondersoek. Daar word geargumenteer dat die wese van die wetenskap en die burokratiese organisasie tot ' $n$ groot mate die oorsaak is van hierdie 'staalhok' verskynsel. Bekende 'staalhokke' van radikale rasionalisasie soos strategiese beplanning, industriële verhoudinge, gedragsmodellering en die persoonlike rekenaar, word bespreek.

S.Afr. Tydskr. Bedryfsl. 1986, 17: 7-12

\section{P. Human}

School of Business Leadership, University of South Africa, P.O. Box 392, Pretoria, 0001 Republic of South Africa
In a recent survey (Barclays Business Brief, April 1985:1) of South African businessmen, it was reported that 'No less than 72 per cent of respondents indicated that they view prospects for the next three months with pessimism, while 28 per cent were reasonably optimistic for the immediate future. There was no unqualified optimism amongst the businessmen surveyed'. A year ago, approximately $75 \%$ of businessmen were still optimistic. Things do seem to be 'falling apart'.

Who or what should be regarded as the culprit for this depressed state of affairs? A popular (and natural) reaction to crises such as this is to accuse factors external to oneself. It is also much easier to accuse factors of an abstract kind; factors which are farthest removed from oneself, such as the mysticisms of the gold price, Reagonomics, the black workforce, or the political policies of the state. It is also interesting to note that these factors are usually perceived as phenomena over which we have no control; phenomena which exist autonomously of our control. The reason why these explanations are so easily accepted is precisely the fact that they make it possible for us to say that we do have no control over them; we are simply the victims of destiny.

I would, however, like to argue that we do have control over our lives; we create our own world and control our own destiny. The blight of the present depressionary state of affairs is, therefore, to be found within ourselves. In this article I propose that many of our problems are a direct result of the way in which we manage. The way in which we manage is an expression of our views and ideas of reality; in other words, of management thought as a system of ideas which shapes social action.

The basic problem in management thought can best be characterized by the term radical rationalization. Radical rationalization means that means are seen as ends-in-themselves, or, in more practical terms, that techniques (as means) are absolutized to the extent that ends are lost from sight. This way of managing is not only ineffective but also immoral.

The critique of the orthodox way of managing, or, as it is better known, scientific management, is a familiar one. One of the central contributions of this article is to arrive at an explanation for the perseverance of scientific management in the face of persistent criticism over the last five decades. Why is it that our actions are in direct opposition to our intentions? I suggest that the reason for the perseverance of scientific management is to be found in the nature of science and the bureaucratic organization. 
the shift from a basically religious world-view to a more secular or rational world-view. Gerth \& Mills (1970:51) saw rationalization as a process of disenchantment; 'The extent and direction of "rationalization" is thus measured negatively in terms of the degree to which magical elements of thought are displaced, or positively by the extent to which ideas gain in systematic coherence and naturalistic consistency'. This rationalistic framework of thought developed historically into the most compelling and universally applied framework that has ever existed.

We can distinguish between three meanings of the concept of rationality. Swidler (1973) suggested that the distinction between rationalism, rationalization and rationality, as it was used by Max Weber, illustrates the three important semantic dimensions of the generic term rationality.

\section{Rationalism}

Rationalism refers to an attitude of pragmatic orientation to the attainment of immediate goals. "It follows rules of experience, though it is not necessarily action in accordance with a means-end schema. Rubbing will elicit sparks from pieces of wood, and in like fashion the mimetical actions of a magician will evoke rain from the heavens' (Weber, 1978a: 400). Rationalism, then, refers to the application of 'effective ways' of doing things in everyday life.

\section{Rationality}

Rationality, in contrast to rationalism, involves the whole meaning of life. It is seen as a system of thought in which the means, ends, and secondary consequences of action are taken into account. Rationality, then, refers to the extent to which action is controlled by conscious ideas. Max Weber's analysis of Protestant asceticism as espoused by Calvin expressed this deliberateness in action governed by conscious ideas most clearly: 'For only by a fundamental change in the whole meaning of life at every moment and in every action could the effects of grace transforming a man from the status naturae to the status gratiae be proved' (Weber, 1978b: 118). This implies the importance of the unified and total control of action by conscious ideas which underlies the Protestant work ethic - the ethic which can be seen as the dominant formative force of our present-day work ethic in capitalism.

\section{Rationalization}

Rationalization refers to the process of the systematization of ideas. The systematization of ideas may mean a number of things. In its most general sense it would simply mean the ordering of a number of discrete elements to arrive at a more precise and internally consistent (logical) whole. Another meaning of rationalization relates to the capacity to integrate new, or irrational ideas, into a system of ideas by finding new, and more abstract, principles to which these ideas are related. The third meaning of the process of rationalization concerns the ability to extend a system of ideas so that it may be applicable to a whole range of situations.

The ability to order, to integrate and to extent inherent in the process of rationalization, implies that a system of ideas can continuously develop in terms of the needs of practical reality (by being flexible and dynamic). Such a relevant, conscious and generalized system of ideas can thus influence and give form to social action.

Given the capacity of rationalization to shape social action and thus to become embedded in both the fabric of social action and the institutions of society means that such an idea system has a 'material base'. This closely connected relation- ship between ideas and material reality would, in turn, guarantee the continued 'relevance' of such an idea system.

From our discussion thus far, it is clear that rationality (in its generic sense) provided a new base for social action. Rationality must therefore be seen as the dominant system of ideas in modern society, and as replacing the transcendental or religious frameworks of pre-industrialized society. It is therefore also clear that management science and thought are to be seen as a product of this general system of ideas.

The bureaucratic form of organization in particular, could be seen as the 'material base' of the rationalistic ethos. The rationalistic ethos is expressed in the material arrangements and principles found in the bureaucratic organization. These two phenomena, the rationalistic ethos and the bureaucratic organization could therefore, in a simplified way, be seen as mirror images of each other.

\section{Radical rationalization}

From the argument above, it would appear that an understanding of the generic term rationality involves an understanding of the means-end nature of social action. Social action must be seen as intentional; we act in order to achieve certain goals or ends. These ends are mostly seen in terms of a satisfaction of needs scheme. The individual human being must be seen as the ultimate end. This means that freedom from wants, self-determination, individual autonomy, and the dignity of the individual in society must be viewed as the ultimate purpose which any system of ideas or form of organization (as means) should serve.

The rationalistic ethos can, in theory, be said to 'serve' this end most effectively. Max Weber associated '. . . the strongest "feeling of freedom" with precisely those actions which we know ourselves to have accomplished rationally, i.e. in the absence of physical or psychic "compulsion"; actions in which we "pursue" a clearly conscious "purpose" by what to our knowledge are the most adequate means' (Löwith, 1982:45). In practice, however, the opposite occurred. Man has become the servant of ideas and organizations; he has lost control over ideas and organizations. They (ideas and organizations) have begun to determine the destiny of man. This process is generally known as the de-humanization and impersonalization of social life. It means that the means of life have become the end; where man once worked (means) in order to satisfy his wants (end), he has now absolutized work, as measured by profits. He has also organized work in such a way that organizational needs transcend individual needs. This process is what we call radical rationalization. This also means that ideas have acquired an autonomous position - they have become divorced from practice to the extent that man is caught in an 'iron cage'. This 'iron cage' is perpetuated through the material base (the bureaucratic organization) and given legitimacy and power 'over' the people in it.

Our ability to solve new problems and to be creative is severely limited by this 'iron cage'. This is the primary thesis of this article. We may, however, ask how this 'irrational' ethos expresses itself in management thought and what it means in practical terms. Let us start with the latter.

\section{The implications of radical rationalization}

Some of the recent literature on management thought employs a critique of the rational model of management as a theoretical basis for its arguments. Peters \& Waterman, in their book In Search of Excellence (1982), seemed to suggest that the attitudes of American companies towards the rational model constitutes the strongest discriminating factor between success- 
ful and unsuccessful companies. McCormack (1984) and Naisbitt (1984) also appeared to suggest that the ultimate cause for many of our problems is to be found in our unqualified acceptance of the rational model as the only valid system of management thought. This critique is in no way new or unique. This critique has been mounting steadily since the days of Frederick W. Taylor (1856-1917). Taylor's work culminated in the movement known as scientific management or, as he sometimes called it, 'the science of shovelling'. Taylor called for a purely scientific approach to work where the task itself, the selection and training of people to perform the task, and the compensation for the execution of the task should be determined by scientific methods (the highest form of rationality).

The consistent critique of Taylorism appears not to have affected the practice of management significantly; my argument will propose an explanation for this. However, it is first necessary to look at the element of this rational model.

\section{Quantification and other limits of science}

The scientific mode of thinking, as the highest form of rationality, places great stress on the systematic and disciplined approach to understanding reality. Reality, it must be remembered, consists of a complex web of a multitude of elements and forces. The function of science is to describe reality and is limited by the methods it employs to describe reality. Einstein once remarked that it is not the function of science to reproduce the taste of soup because science cannot reproduce reality; it can merely offer parochial descriptions of it. A description of the taste of soup is not the same thing as the taste of soup itself. The point is that we must accept the fact that the scientific endeavour can never fully come to grips with the totality of a phenomenon.

Scientific analysis can only produce accounts of reality in terms of its instruments. These instruments (of measurement, for example) can only measure that which is empirically observable and thus quantifiable. The high premium placed on disciplined inquiry also means that the reproducibility of results is highly valued. Underlying the reproducibility of research findings is the idea that general laws govern all situations and that it is the function of science to discover these general laws (the function of extending ideas as discussed above under the process of rationalization).

The end-result is that science has created a notion of the 'truth' where only that which is quantified, standardized and systematic is true. The point is, however, that reality also includes qualitative components; that some phenomena are at times unique (situationally-bound) and at times extremely unsystematic and chaotic. Science, in its orthodox sense, is, at best, only able to produce partial and limited descriptions of reality. It should never, in the absolute sense, be seen as our only instrument for understanding reality.

But science not only produces a narrow and sometimes distorted picture of reality, it also reproduces a conservative and formalistic approach to life. The rules of the scientific method are highly formalized and not very flexible. The reason for this is to be found in the high premium placed upon the reproducibility of results. These rules are also transmitted to students of science in such a way as to make their validity unquestionable. Not only this but also the myth that the conscientious application of these rules will 'automatically' produce the 'truth' gives the scientific method an aura of legitimacy. The result of this is that science, especially as it is applied in the sphere of business, has become an uncritical and thus conservative mode of thinking. I will return to this point at a later stage.

\section{Substantive versus formal rationality}

Substantive rationality '. . . is the degree to which the provisioning of given groups of persons . . . with goods is shaped by economically-oriented social action under some criteria . . . of ultimate values' (Weber, 1978a:85). Formal rationality, in constrast, relates to ' . . the extent of quantitative calculation or accounting which is technically possible and which is actually applied ... the degree in which the provision for needs . . . is capable of being expressed in numerical, calculable terms' (Weber, 1978a:85).

It is therefore clear that the means in substantive rationality will be determined by ultimate values. These ultimate values are related to the full range of needs of the individual. An analytic distinction between means and ends is drawn without negating the important connection that exists between those two spheres of social action. In formal rationality, we find no clear distinction between means and ends. The means and the ends are in no way clearly distinguished because the criteria for assessing needs (ends) and the means to provide for these ends are the same. We know that the individual human being cannot be reduced to 'numerical calculable terms'. Formal rationality, then, is blind to the full meaning of human existence.

Modern management thought follows the lines of formal rationality rather than substantive rationality. The reason for this, in a theoretical sense, is that means have come to be seen as ends with the results that the technological and calculable needs of the organization transcend the needs of the individual.

\section{The nature of the bureaucratic organization}

I have argued that the 'material base' of the rationalistic ethos is, in particular, to be found in the modern bureaucratic organization. The bureaucratic form of organization has become the single most important structural arrangement in modern society. South Africa is no exception. I, and many other writers, have indicated the extent of bureaucratization in South Africa (see Human, 1984). The conclusion arrived at about the concentration of economic power in South Africa, is that the majority of the population are employed by large bureaucratic organizations. The way of thinking expressed by such organizations surely must have an effect on the way of thinking of those who work in them.

The bureaucratic ethos will express the interests of the bureaucratic organization. Calculability, efficiency, control specialization (through the fragmentation of tasks as the most rational method of production), hierarchical distribution of power, etc. are all values highly regarded by the bureaucratic organization. Any organization produces certain interests which it would wish to reproduce and extend. This is only possible by the creation of ideas which support and further the interests of the organization.

If one contrasts the ideal nature of the individual with that of the bureaucratic organization in terms of a number of dimensions developed thus far (Table 1), you can obtain some 'feeling' for the problems facing industrialized society.

These two realities are necessary prerequisites for the production of goods and services; organizations cannot exist without individuals in the same way as individuals cannot exist without organizations. The answer to many of our problems lies in the way in which these two realities are combined.

Our argument so far, has been that management thought has over-accentuated organizational reality at the expense of individual reality. The organization has become an end in itself. A way of thinking has developed (an 'iron cage') which 
Table 1 Comparison between the nature of the individual and that of the bureaucratic organization

\begin{tabular}{ll}
\hline The individual & The organization \\
\hline Substantive rationality & Formal rationality \\
Subjective need satisfaction & Objective need satisfaction \\
Concrete expectations & Abstracted expectations \\
Decisions as to ends & Decisions as to means \\
Qualitative & Quantitative \\
Free will & Determinism \\
Holistic view of reality & Fragmention of reality \\
(Specialization)
\end{tabular}

fragments and distorts reality by its exclusive fixation on specialization and quantification. The conservative and formalistic nature of this way of thinking inhibits the ability of managers to understand the true nature of their business, in the first place, and, in the second place, to be creative and truly problem-solving. The source of this way of thinking is to be found in the rationalistic ethos which is formalized in science and expressed in the nature of the formal organization. The apparent legitimacy of science as well as the nature of the formal organization ensures the reproduction of the 'iron cage' way of thinking.

\section{Familiar 'iron cages'}

\section{Strategic planning}

Lenz (1983) wrote that hyper rationality '... is a condition in which the entrepreneurial spirit essential for planning is supplanted by rigidity, excessive quantification and formality. Once hyper-rationality exists, the capacity of the planning process to insure innovative adaptation is lost. With this loss comes a diminished capacity of an organization for achieving long-term competitive success'. Lenz discussed four causes for the 'hyper-rational' state of strategic planning. The first is the professionalization of the planner's job. In days gone by, no such profession existed. With the growth in the need for specialization in the large bureaucracies, business schools and large business firms were quick to single out strategic planning as a career. 'A requirement for maintaining the professional mystique of planning is to cast it into the mold of an exact science ... First came the necessary jargon. Terms such as strategic business unit, growth-share matrix, and GAP analysis became buzz words of the planning professional' (Lenz, 1983:4). The growth of the subject, as a multi-disciplinary one, quickly degenerated into a body of obscure terms and fancy techniques. This obviously served the interests of planners, who, as staff vis-à-vis line managers, felt vulnerable with respect to their organizational status. The results was that the subject strategic planning became increasingly obscure and a mere collection of techniques. The techniques became absolutized at the expense of the end - and that is to plan to achieve a specific end. This is also true for many other specialized staff functions in business practice. Lenz also mentioned the quantification equals certainty fallacy, the institutionalization of planning, and the unqualified acceptance of analytical techniques as the other three causes for 'hyperrationality'. The point is that increasing technical sophistication can breed increasing irrelevance.

\section{Industrial relations}

The practice of industrial relations in South Africa is another familiar 'iron-cage'. Industrial relations is a multi-disciplinary subject which has as goal the regulation of the relationship between labour and management. The legal aspect of industrial relations is only one aspect of the totality of the relationship. However, a tendency exists in the industrial relations sphere to reduce this relationship to its legal dimension. This is evident in South Africa in the high proportion of legal people involved in the industrial relations function. This implies a number of dangers, inter alia:

- the legal aspects of the relationship between employer and employee are absolutized.

- the legal machinery (as expressed in the Act on Labour Relations) is seen as the only framework in terms of which this relationship is to be regulated.

- disputes between labour and management can be 'solved' in a win-lose manner.

We know that the legal dimension to industrial relations is only one and not the only regulatory mechanism. To reduce industrial relations to the legalistic framework is to distort the 'real' nature of the relationship. This reduction also excerbates rather than ameliorates the relationship between labour and management. Given the interdependency between labour and management, it is clear that any thoughts of ultimately 'solving' problems in a legalistic win-lose manner is, to say the least, absurd. But this is exactly what is happening; the unnecessary legalistic bias built into industrial relations practice has created the belief that disputes can be ultimately 'solved'.

The accentuation of the legal aspects in industrial relations is perhaps a reflection of the immaturity of industrial relations practice in this country. Otto Kahn-Freund once remarked that: 'There exists . . . something like an inverse correlation between the practical significance of legal sanction and the degree to which industrial relations have reached a state of maturity ... Reliance on legislation and on legal sanctions for the enforcement of rights and duties between employers and employees may be a symptom of an actual or impending breakdown and, especially on the side of the unions, frequently a sign of weakness, certainly not a sign of strength' (Wedderburn, Lewis \& Clark, 1983:41). This immaturity is, in my eyes, directly related to a limited and conservative ('narrow') conception of industrial relations amongst practitioners.

\section{Behavioural modelling}

Behaviour modelling is a popular technique used by management to increase the effectiveness of employees. The argument is that it is easier to change the behaviour of the employees than their attitudes. If one can change behaviour successfully, then attitude change will follow, according to dissonance theory. The aim of behaviour modelling is not to '. . . directly attempt to change the attitudes of the participants; it rather aims to offer them with a broader behavioural repertoire by providing them with knowledge and practice of alternative, more adaptive behaviour in a variety of job-relevant situations (Hofmeyr, 1983:14).

The general idea is basically sound (see Bumaska, 1976 and Schneier, 1973). It is, however, rather in the application of this technique that many unintended negative consequences arise. Parry \& Reich (1984) examine some of these shortcomings. The model as it is applied is too simplistic. The model is seen by instructors as an end-all rather than the starting point it was intended to be. The model is seen as of general use and not sensitive to specific situational conditions. It furthermore only concentrates on correct behaviour much can be learned from incorrect or inappropriate behaviour. In short, it would seem that the model is seen as an 
end in itself; it is narrow and the skills learned by particpants are not always appropriate to the situation.

The personal computer and 'technofix'

The enormous growth in the use of computers in the business world constitutes one of the most important observable changes that have taken place in the work sphere in the last decade. It is, however, questionable whether their popularity correlates with their usefulness. It is my contention that the usefulness of computers is overestimated and that the growth in computer usage may in fact have had certain negative effects on our ability to manage effectively. Steven Wozniak, the co-founder member of the Apple Computer Company, recently said: 'People believe that because computers do things differently they do them better. It takes a few years of playing with them to find out it isn't true' (The Star, 28 January, 1985). But the point is not only that computers are not necessarily able to do things better; they may actually encumber rather than assist. In education, for example, critics argue that the computer as an educational tool may actually be harmful inasmuch as it crowds out the real substance of learning with time-wasting procedures and gadgets. This is also true for the appliction of computers in business. Naisbitt (1984:51) wrote: 'Man is a clever animal. There is no way to keep him from devising new tools. The error lies in thinking that new tools are the solution. It could be a fatal error'.

Computers, and for that matter, all techniques and technologies, should be seen as mere extensions of our physical and mental abilities; that is exactly what they are. They are as such no more than tools which may assist us; they may make life easier by eradicating repetitious and time-consuming tasks. Computers, however, in no way represent an alternative to our abilities. The point is therefore that the fault is not to be found in the computer per se, but in our attitudes towards computers.

\section{Job evaluation}

Job evaluation schemes instituted by management in industry are regarded as important by a personnel manager interviewed by Mathews (1985:28), because they ' . . systematise(s) the whole personnel function'. Such schemes, according to this respondent, are also invaluable in the face of union agitation inasmuch as they generate a defensible, logical, scientific pay structure which he hoped would, for these reasons, not be challenged by workers or the union. Management, in this instance, seek legitimacy for their actions in the name of scientific validity. We all know, however, that any job evaluation scheme is limited in terms of the number of variables it can take into account in assessing the real value of a worker. These variables are also based upon certain assumptions which, collectively, define our notion of the value of a worker. Given the abstract, almost philosophical, basis of job evaluation schemes it is clear that the scientific argument for their legitimacy is, to say the least, suspect. There exists, for example, no way in which one can adequately quantify assumptions such as decision-making, variety of tasks, work pressure, etc. It is clear that job evaluation schemes are, in practice, quantified conceptions of the value of workers.

Given the variance one expects to find in the subjective experiences of people to similar situations, it is clear that any job evaluation scheme will only be a rough approximation of the value of workers and no guarantee for substantive fairness.

We would all agree on the necessity of some scheme to evaluate jobs. Such evaluation is a pre-condition for both the efficiency of production and the fairness of compensation. It is, however, wrong to assume that:

- job evaluation systems would solve all our problems related to the grading of employees;

- they would be perceived as 'fair' because they are scientific. We should rather see such systems as general guidelines in our assessment of jobs which are, of themselves, not the only means by which this goal could be achieved. These schemes are scientifically suspect, limited to quantifiable aspects and some times unnecessarily complicated. Mathews (1985:28) stated in her case study on the introduction of the Paterson scheme in a factory in Cape Town that: 'Far from eliminating conflict in collective bargaining, management therefore increased the terrain of disagreement between them and the union by the introduction of the Paterson system'.

\section{What is to be done?}

It has been argued earlier that the critique against the rationalscientific model seems to be well-known and accepted by many as valid. The problem is, however, that the rational-scientific management approach seems to still dominate management thinking in spite of this critique. I suggest that the reason for this could be an insufficient understanding of the bases and causes underlying this way of thinking. Most analyses seem to fail to come to grips with the historical and structural reasons for its existence. These analyses tend to argue that 'it is there and should be avoided'. It is my contention that no problem can be 'solved' until it is fully understood.

So when asked 'What is to be done?', my answer is that one should address this problem in two ways: The first way is to create an 'awareness' that many of our problems are related to radical rationalization. This awareness will lead to a questioning of our assumptions about management thought; a critical mind always presupposes an awareness that 'all is not well'. This awareness will naturally lead to a quest for, in the first place, the causes for this unhappy condition, and secondly, for alternatives.

We have already suggested two primary causes for the persistence of scientific management, namely science and the large bureaucratic organization. As far as science itself is concerned, it is of utmost importance to realize that the body of knowledge produced by scientists is not as valid and as clear-cut as it would appear to be. Most scientists would readily admit to this. The problem is, however, that the language of science is highly obscure and scientific 'facts' are generally accepted purely because very few people understand what they really mean. In their obscurity lies much of their marketability! The problem with scientists is that they do not produce their ideas in readily applicable terms - this is done by others, such as consultants, who are not familiar with the peculiarities of the scientific language.

The way in which science is transmitted and those institutions which transmit science reproduce the crippling effects of radical rationalization. Let us look briefly at Business Schools. Business schools are semi-academic and semi-practical institutions. Academics are oriented towards the discovery of the 'truth' whilst practical reality is concerned with the 'usefulness' of phenomena. The business school is thus torn between these two orientations; it has to be 'academic' because it is partly dependent upon the university for its existence and it also has to be 'practical' because it draws students from the world of business. One can argue that the natural reaction of the business school would be to play these two interests off against each other. By this I mean to either satisfy the needs of business by providing them with problem-solving 
techniques dressed in an academic cloak, or to teach students theory and try to translate this theory into practice. The former is, however, the least taxing on our intellectual and physical abilities.

Business schools should ask themselves (again) what business they are in? Do we want to train people or do we want to educate them? Are we not too reactive to the demands of business? Should we not lead the business community rather than merely equipping it with the skills and techniques which it demand? I believe that the future of our business schools will be determined by the extent to which they clearly formulate their role in the business community and when they start leading the business community rather than following it. Business schools will only be able to lead, however, if the values of creativity and innovation are again instituted as crucially important academic values. Related to this is the institutionalization of a research-oriented culture - that is, a culture in which inquisitiveness and a critical quest for understanding are the dominant values.

The second reason why radical rationalization perseveres is to be found in the large bureaucratic organization. It is a fact of life that one is (and that would include the way in which we think) a product, to some extent, of one's environment. The large bureaucracy produces a way of thinking which is fragmented, formalized and rigid. It produces a way of thinking directly opposed to that of the entrepreneurial way of thinking. It absolutizes rules and procedures, supresses free will and creativity, and it abhors experimentation.

It is not the size of the organization itself which is the culprit but rather the lack of awareness on the part of its 'inmates' of the crippling effects their environment may have on their mental capacities.

Apart from these two major causes of radical rationalization to which we should give our attention, I also believe that the individual in the organization can effectively resist radical rationalization. The starting point is obviously to be aware of the causes and nature of radical rationalization. This is a precondition for the cultivation of an intrapreneurial (Times, 4 February 1985) way of thinking. Intrapreneurial thinking refers to the cultivation of an entrepreneurial spirit within the large bureaucratic organization.

This means that the individual should redefine him/herself as a free and an autonomous person as opposed to someone completely determined by his environment. The same would apply to the organization as a living organism. Some of the questions both the individual and the organization should ask themselves include:

- Do we understand what our ends are? By this, a conceptual distinction between ends and means is also implied; do we apply the most effective means to achieve a specific goal? Is this technique or skill really crucial to the attainment of a goal?

- Are we competent when it comes to the basics?

- Do we have a sound picture of the whole? Are we sure that we have taken all the relevant information (qualitative as well as quantitative) into account?

- Do we encourage and reward entrepreneurial initiative?

\section{Conclusion}

In this article I have argued that the radical rationalization of management thought strongly correlates with our inability to be creative managers. Many of our problems are also a direct function of this way of thinking. The term radical rationalization refers to a way of thinking which is rigid, formalized, fragmented, narrow, quantitative, and in which means are seen as ends in themselves. I have also argued that the primary cause for this way of thinking should be sought in the nature of science and in the bureaucratic form of organization; it is also through these two phenomena that this way of thinking is reproduced and maintained.

As regards our approach to rectify this situation, I have argued that the solution lies, firstly, in an awareness of the nature of the problem and, secondly, in the nature of science and the bureaucratic form of organization.

\section{References}

Barclays Business Brief. April 1985. Johannesburg: Barclays Bank. Burnaska, R.G. 1976. The effects of behavior modeling training upon manager's behaviors and employees' perceptions. Pers. Psychol. vol. 29, $329-335$.

Gerth, H.H. \& Mills, C.W. 1970. From Max Weber: Essays in Soriology. London: Routledge and Kegan Paul.

Hofmeyr, K. 1983. The role of the instructor in behaviour modelling. Manpower J., vol. 2(8), 14-17.

Human, P. 1984. Bureaucracy and the Need for Entrepreneurship in South Africa. S. Afr. J. Bus. Mgmt. vol. 15(4), 212-219.

Lenz, R.T. 1983. Crippling Effects of 'Hyper-Rational' Planning. Faculty Working paper No. 956. Bureau of Economic and Business Research, University of Illinois, Urbana-Champaign.

Löwith, K. 1982. Max Weber and Karl Marx. London: George Allen and Unwin.

Mathews, C. 1985. Case Study: The Paterson System at a Factory in Cape Town. S. Afr. Labour Bull., vol. 10(4), 25-28.

McCormack, M. 1984. What they don't teach you at Harvard Business School. London: Collins.

Naisbitt, J. 1984. Megatrends. New York: Warner Books.

Parry, S. \& Reich, L. 1984. An uneasy look at behaviour modelling. Training Developm. J., vol, 38(3), 57-62.

Peters, T. \& Waterman, R. 1982. In Search of Excellence. New York: Harper and Row.

Schneier, C.E. 1973. Behaviour modification: Training the hardcore unemployed. Personnel, vol. 50, 65-69.

Swidler, A. 1973. The Concept of Rationality in the Work of Max Weber. Sociological Inquiry, vol. 43(1), $35-42$.

The Star, 28 January 1985.

Times, 4 February 1985.

Weber, M. 1978a. Economy and Society (vol. 1 \& 2). Berkeley: University of California Press.

Weber, M. 1978b. The Protestant Ethic and the Spirit of Capitalism. London: George Allen and Unwin.

Wedderburn, L., Lewis, R. \& Clark, J. 1983. Labour Law and Industrial Relations: Building on Kahn Freund. Oxford: Clarendon Press. 